Kumawula, Vol. 1, No.2, Agustus 2018, Hal 90 - 103 DOI:http://10.24198/kumawula.v1i2.19794

ISSN 2620-844X (online)

Tersedia online di http://jurnal.unpad.ac.id/kumawula/index

\title{
SOSIALISASI MENGENAI PERDAGANGAN MANUSIA (HUMAN TRAFFICKING) DALAM UPAYA PENCEGAHAN TINDAK PIDANA PERDAGANGAN ORANG (TPPO) DI KECAMATAN TEMPURAN KABUPATEN KARAWANG
}

\author{
SOCIALIZATION OF HUMAN TRAFFICKING IN THE ELIMINATION OF \\ HUMAN TRAFFICKING CRIMES IN TEMPURAN DISTRICT, KARAWANG \\ REGENCY
}

\author{
Chandra Purnama ${ }^{1 *}$, Windy Dermawan ${ }^{2}$, Emil Mahyudin $^{3}$ \\ 1, 2, 3 Dosen pada Departemen Hubungan Internasional Universitas Padjadjaran \\ *chandra.purnama@unpad.ac.id
}

\begin{abstract}
The community development activity (PPM) aims to provide understanding to the community regarding human trafficking and prevention efforts in Tempuran District, Karawang Regency. To achieve this goal, we carry out socialization activities on human trafficking, the danger posed is based on a human security perspective and prevention efforts so that the community is empowered to counter these threats in Tempuran District, Karawang Regency. The methods of PPM use the Problem Based Learning and Community Based Research (CBR) in the formulation of an idea that suits the needs of the community in solving the problem.. The PPM activity concludes that prevention of trafficking needs to be carried out continuously and cross-sectorally because the mode of crime has developed and varied. There was a strengthening of the knowledge and understanding of the Tempuran District community in responding to the importance of preventing human trafficking through improving education, living standards, parental roles and community supervision. Thus, the PPM activity was able to increase knowledge about human trafficking and encourage participants' awareness to jointly prevent human trafficking in Tempuran District, Karawang Regency.
\end{abstract}

Keywords: Socialization, human trafficking, prevention.

\begin{abstract}
ABSTRAK
Kegiatan pengabdian pada masyarakat (PPM) ini bertujuan memberikan pemahaman kepada masyarakat mengenai perdagangan manusia dan upaya pencegahannya di Kecamatan Tempuran Kabupaten Karawang. Untuk mencapai tujuan tersebut, kami melaksanakan kegiatan sosialisasi mengenai perdagangan manusia, bahaya yang ditimbulkannya berdasarkan perspektif keamanan manusia dan upaya pencegahan agar masyarakat berdaya untuk menangkal ancaman tersebut di Kecamatan Tempuran Kabupaten Karawang. Kegiatan PPM ini menggunakan metode Problem Based Learning dan Community Based Research (CBR) di dalam merumuskan gagasan yang sesuai dengan kebutuhan mereka dalam upaya memecahkan permasalahannya. Kegiatan PPM ini menyimpulkan bahwa pencegahan perdagangan manusia perlu dilakukan secara berkesinambungan dan lintas sektoral karena modus dari tindak pidana ini telah berkembang dan beragam. Terdapat penguatan pengetahuan dan pemahaman masyarakat Kecamatan Tempuran dalam menanggapi pentingnya pencegahan
\end{abstract}


perdagangan manusia melalui peningkatan pendidikan, taraf hidup, peran orangtua dan pengawasan masyarakat. Dengan demikian, kegiatan PPM ini mampu meningkatkan pengetahuan mengenai perdagangan manusia dan mengugah kesadaran peserta untuk bersama-sama mencegah perdagangan manusia di Kecamatan Tempuran Kabupaten Karawang.

Kata kunci: sosialisasi, perdagangan manusia, pencegahan.

\section{PENDAHULUAN}

Era globalisasi memberikan kemudahan dalam migrasi barang, jasa, modal dan bahkan manusia dari satu negara ke negara lainnya. Hal ini memberikan dampak positif maupun negatif. Salah satu dampak negatif dari globalisasi yaitu munculnya tindak kriminal yang melintasi batas negara, atau yang dinamakan sebagai transnational crime. Salah satu bentuk kejahatan transnasional yang berkembang di Indonesia yaitu perdagangan manusia (Human Trafficking) ${ }^{1}$. Perdagangan manusia menguat menjadi perhatian internasional seiring dengan munculnya konsep keamanan manusia (human security). Di era pertengahan tahun 1990-an, konsep keamanan manusia menunjukkan pengaruhnya dan menjadi tantangan bagi tatanan politik dunia, institusi, dan pemerintahan (Oberleitner, 2007). Konsep yang mencuat pasca Perang Dingin ini langsung mendapat perhatian dari kalangan pengkaji keamanan dan pembuat kebijakan negara. Keamanan manusia merupakan suatu keamanan yang komprehensif, terintegrasi, berkesinambungan dari rasa takut, konflik, kebodohan, kemiskinan, perampasan sosial dan budaya, yang bertumpu pada kebebasan positif dan negatif (Ginkel \& Newman, 2000).

Keamanan manusia dapat ditinjau dari dua aspek, pertama, yaitu keamanan dari ancaman kronis seperti kelaparan, wabah penyakit dan represi. Kedua, perlindungan dari gangguan yang menyakitkan dalam pola kehidupan sehari-hari, baik di rumah, tempat kerja, atau di masyarakat (Paris, 2001). Konsep ini terkait dengan segala keamanan fisik dan psikologis. Thomas \& Wilkin (1999) menyederhanakan konsep keamanan manusia dengan hanya berpacu pada penyediaan "basic material needs" dan realisasi "human dignity". Gasper (2005) menyatakan tujuan dari keamanan manusia yaitu pengembangan manusia dengan perhatian pada aspek keamanan fisik individu di luar kajian keamanan militer dan negara. Dari berbagai penjelasan tersebut, maka perdagangan manusia terkait erat dengan konsep keamanan

\footnotetext{
${ }^{1}$ Undang-Undang Nomor 21 Tahun 2007 tentang Pemberantasan Tindak Pidana Perdagangan Oarng mendefinisikan perdagangan manusia, yaitu, "tindakan perekrutan, pengangkutan, penampunangan, pengiriman, pemindahan, atau penerimaan seseorang dengan ancaman kekerasan, penggunaan kekerasan, penculikan, penyekapan, pemalsuan, penipuan, penyalahgunaan kekuasaan atau posisi rentan, penjeratanutang atau memberi bayaran atau manfaat, sehingga memperoleh persetujuan dari orang yang memegang kendali atas orang lain tersebut, baik yang dilakukan di dalam negara maupun antarnegara, untuk tujuan eksploitasi atau mengakibatkan orang tereksploitasi”.
} 
manusia dimana perdagangan manusia merupakan bentuk dari ancaman terhadap keamanan manusia yang telah melanggar nilai-nilai kemanusiaan, hak hidup, keamanan dari tekanan, dan pelanggaran terhadap martabat manusia itu sendiri. Dalam narasi trafficking, korban sebagian besar dikenali secara pasif, mereka tergambarkan tidak berdaya dan kurangnya perhatian agensi (Andrijasevic, 2014). Penjahat atau oknum mengambil tindakan untuk memperbudak korban, sementara pahlawan mengambil tindakan untuk membebaskan mereka. Dua aktor ini diklaim sebagai aktor kuat dalam narasi trafiking, pada suatu posisi untuk mengambil tindakan dalam membebaskan korban dari perbudakan modern (O’Brien, 2018).

Perdagangan manusia merupakan salah satu masalah serius dalam kehidupan manusia. Bahkan, aktivitas kejahatan ini menempati industri ilegal kedua secara global setelah perdagangan minuman keras (Sallie, 2010). Tindak kejahatan perdagangan manusia berkembang karena didukung oleh posisi geografis Indonesia, selain karena masalah ekonomi, dan budaya permisif di daerah-daerah tertentu di Indonesia. Wilayah Indonesia yang sangat luas dan dilalui oleh lalu lintas pelayaran internasional, serta masih terdapat titik-titik perbatasan yang minim dari penjagaan aparat keamanan sehingga memudahkan para pelaku kejahatan perdagangan manusia, khususnya perdagangan perempuan dan anak dengan modus pengiriman TKI ke luar negeri, padahal dalam kenyataannya diperdagangkan di tempat hiburan malam maupun di tempat prostitusi. Laporan dari The United Nations Office on Drugs and Crime (UNODC) menunjukkan bahwa 71\% korban perdagangan manusia adalah perempuan muda dan dewasa serta anak-anak. Laporan tersebut juga menunjukkan bahwa tujuan dari perdagangan manusia adalah untuk eksploitasi seks, kawin kontrak, perbudakan, pengemis, dan industri pornografi (UNODC, 2017).

Pada akhir Perang Dingin, isu perdangangan manusia semakin marak diperbincangkan sebagai bagian dari konsep keamanan nontradisional. Keamanan nontradisional ini tidak memfokuskan pada ancaman keamanan terhadap eksistensi negara dari serangan militer negara lain atau peningkatan kapabilitas militer suatu negara, tetapi lebih kepada eksistensi keberlangsungan manusia di muka bumi, di dalam penanganannya pun tidak hanya diemban oleh negara dengan kebijakan domestik, tetapi juga memerlukan kerjasama transnasional antaraktor baik negara maupun nonnegara.

Karawang merupakan salah satu kabupaten di Provinsi Jawa Barat yang menjadi sasaran bagi praktek perdagangan manusia. Bahkan, Kabupaten Karawang masuk ke dalam tiga besar kasus perdagangan mansia di Jawa Barat (https://www.faktajabar.co.id/2018/07/04/karawang-rangking-3-trafficking-di-jawa-barat/). 
Hasil dari penelitian Kementerian Pemberdayaan Perempuan dan Perlindungan Anak (PPPA), perempuan di Karawang rentan terbujuk tawaran bekerja ke luar negeri menjadi TKW yang akhirnya menjadi korban perdagangan manusia. Dari sejumlah kejahatan yang terjadi di Jawa Barat dan ditangani oleh biro hukum Polda jabar, kasus trafficking sebagai bentuk kasus kejahatan transnasional mengalami kenaikan di tahun 2017 sebanyak 52 perkara dari 34 perkara pada tahun 2016 (Permadi, 2017). Berdasarkan hasil survey ke seluruh wilayah Karawang oleh Yayasan Kusuma Buana, diketahui bahwa terdapat 12 kecamatan yang menjadi kantong perdagangan manusia dan kekerasan terhadap perempuan dan anak (Winarsih, 2017).

Perdagangan manusia terjadi secara massif disebabkan oleh berbagai faktor, diantaranya meningkatnya kemiskinan dan angka putus sekolah di Indonesia, kesempatan kerja yang terbatas, konflik sosial di berbagai daerah, lemahnya peran lembaga keluarga dan masyarakat dalam mengontrol dan mencegah terjadinya praktek perdagangan manusia (Sapardjaja, 2003). Karawang memang bukan termasuk sumber perdagangan manusia seperti Indramayu, Subang dan Sukabumi. Namun, arah kecenderungan perdagangan manusia ke luar negeri di Karawang menunjukkan peningkatan. Hal ini karena posisi strategis Karawang sebagai salah satu wilayah penyangga ( $b u f f e r$ zone) bagi Ibu Kota Jakarta yang telah mendorong adanya perubahan kebijakan dari pertanian menjadi kawasan industri. Perubahan ini memberikan dampak pada perubahan pola hidup masyarakat Karawang yang menuntut mereka untuk mencari kerja ke luar negeri sebagai pilihan rasional sehingga rentan menjadi korban perdagangan manusia, terutama perempuan dan anak (Pudjiastuti, Wuryandari, \& Nur Alami, 2016). Hasil survey KAMI menyebutkan bahwa perdagangan manusia di Kabupaten Karawang paling banyak terjadi di wilayah pelosok dan pesisir yang angka kemiskinannya terbilang tinggi. Hal ini dikarenakan kurangnya pengetahuan terhadap masyarakat di wilayah tersebut, seperti di Kecamatan Cilamaya Wetan (Pojok Jabar). Di Kabupaten Karawang, ternyata masalah ekonomi bukanlah satu-satunya faktor yang utama di dalam perdagangan manusia. Dalam perspektif Hubungan Internasional, faktor keamanan, lingkungan sosial, konstruksi sosial dan keterbatasan pendidikan dapat menjadi faktor pemicu maraknya permasalahan perdagangan manusia di Kabupaten Karawang (Sidebang, 2018).

Terkait pencegahan perdagangan manusia, di Kecamatan Cilamaya Wetan, Kementerian Pemberdayaan Perempuan dan Perlindungan Anak (Kemen PPPA) Republik Indonesia membentuk Komunitas Pencegahan Tindak Pidana Perdagangan Orang (PP-TPPO) tingkat Kabupaten Karawang. Pemerintah Kabupaten Karawang pun telah berusaha mencegah terjadinya kasus perdagangan perempuan, salah satunya dengan mengeluarkan Peraturan 
Daerah Kabupaten karawang Nomor 7 Tahun 2012 mengenai Pencegahan dan Penanganan Perdagangan Manusia. Untuk menindaklanjuti perda tersebut, Pemerintah Daerah juga telah bekerjasama dengan lembaga pemerintah lainnya dan LSM untuk aktif dalam kampanye pencegahan perdagangan manusia. Namun demikian, payung hukum pencegahan perdagangan manusia ini belum dipahami secara maksimal di kalangan masyarakat bawah, sehingga kegiatan sosialisasi mengenai pencegahan perdagangan manusia mutlak diperlukan sebagai bagian dari membangun kesadaran masyarakat terhadap ancaman perdagangan manusia sekaligus pengawasan bagi masyarakat dalam mencegah ancaman tersebut.

Berdasarkan analisis permasalahan terhadap wilayah kegiatan di Kecamatan Tempuran Kabupaten Karawang, diketahui bahwa warga di Kecamatan Tempuran Kabupaten Karawang masih memiliki keterbatasan pengetahuan atau wawasan mengenai perdagangan manusia dan upaya pencegahannya. Sejalan dengan hal tersebut, pemasalahan dapat diuraikan berikut ini.

1. Para aparat desa memiliki keterbatasan pengetahuan mengenai perdagangan manusia dan upaya pencegahannya;

2. Para orang tua, perempuan dan anak-anak di Kecamatan Tempuran belum memiliki pemahaman utuh mengenai perdagangan manusia dan upaya pencegahannya;

3. Pencegahan perdagangan manusia dilakukan melalui upaya preventif dan humanis yang sejalan dengan nilai-nilai lokal masih terbatas diwacanakan, khususnya di kalangan pelajar di Kecamatan Tempuran;

4. Banyaknya sponsor yang mengajak kerja ke luar negeri, terutama sasarannya yaitu perempuan dewasa dan remaja, baik sponsor TKI resmi maupun ilegal, sehingga perlu diantisipasi dengan pemberian pengetahuan mengenai prosedur resmi kerja di luar negeri, saluran kerja dan tantangannya;

5. Arus media informasi dan komunikasi yang berkembang memudahkan para calo atau perusahaan TKI ilegal untuk melakukan rekruitmen bagi calon TKI di Kabupaten Karawang, khususnya bagi para pelajar yang telah mengenal penggunaan gajet sebagai produk teknologi.

Atas dasar uraian di atas, kami berupaya untuk merespon permasalahan tersebut dengan melaksanakan sosialisasi perdagangan manusia dan pencegahannya sebagai bagian dari Pengabdian Pada Masyarakat (PPM). Tujuan pelaksanaan kegiatan ini adalah meningkatkan pemahaman warga mengenai perdagangan manusia dan membekali mereka agar mampu menjadi agen dalam melakukan pengawasan sebagai bagian dari upaya pencegahan praktek perdagangan manusia. 


\section{METODE}

Kegiatan ini menggunakan metode Problem Based Learning dan Community Based Research (CBR) di dalam merumuskan suatu ide-ide yang sesuai dengan permasalahan yang dihadapi masyarakat sehingga kebutuhan masyarakat dapat tercapai. CBR ini merupakan suatu model riset dengan melibatkan peserta sebagai bagian dari komitmen mereka dalam mendukung sumberdaya dan keterlibatan dalam proses kegiatan sehingga dapat menghasilkan produk yang bermanfaat bagi pihak terlibat (Banks \& Manners, 2012).

Teknik pengumpulan data di dalam pelaksanaan PPM ini dilakukan melalui wawancara terhadap sejumlah informan, diantaranya dengan perangkat desa, aparat keamanan (polsek Tempuran), tokoh masyarakat dan korban trafiking yang ada di Kecamatan Tempuran Kabupaten Karawang. Untuk menunjang pengumpulan data, kegiatan ini juga melaksanakan observasi berperan serta di daerah yang rawan terjadinya perdagangan manusia, yaitu di Kecamatan Cilamaya Wetan. Selain itu, studi dokumentasi dilakukan dengan menggali sejumlah literatur dan dokumen yang terkait dengan permasalahan yang diangkat. Untuk mencapai tujuan dari kegiatan ini, kami menyusun tahapan kegiatan, diantaranya yaitu:

1. Pra-Survey dan analisis lingkungan melalui kegiatan silaturahmi kepada stakeholders setempat

2. Wawancara dengan pihak korban Perdagangan Manusia di Kecamatan Cilamaya Wetan

3. Focus Group Discussion dengan stakeholders di Kecamatan Tempuran

4. Diskusi dan nonton bareng film "Whistleblower" dengan Masyarakat di Kecamatan Tempuran

5. Sosialisasi pencegahan Perdagangan Manusia terhadap siswa di SMAN 1 Tempuran

Kegiatan tersebut merupakan bentuk dari kegiatan kognitif, afektif dan psikomotorik yang bisa memberikan pemahaman, membangkitkan kesadaran dan berupaya bersama-sama di dalam mencegah dan mengatasi perdagangan manusia di Kecamatan Tempuran Kabupaten Karawang, Provinsi Jawa Barat.

Adapun peserta yang terlibat dalam kegiatan PPM ini terdiri dari perangkat desa, aparat keamanan (TNI dan Polri di Kecamatan Tempuran), tokoh masyarakat, tokoh pemuda (Karang Taruna), guru dan siswa SMA di Kecamatan Tempuran dan orangtua siswa. Kegiatan ini dilaksanakan selama 4 bulan, dari mulai Agustus hingga November 2018. 


\section{HASIL DAN PEMBAHASAN}

Kegiatan ini merupakan upaya penyadaran terhadap masyarakat dengan melibatkan berbagai elemen masyarakat, sehingga di dalam pelaksanaannya terdapat dialog dan upaya membangkitkan sikap sosial untuk pencegahan perdagangan manusia bersama-sama. Pendampingan dan fasilitasi juga diperlukan dalam rangka mengontrol proses-proses selanjutnya, sehingga keberadaan dan kelanjutan program ini dapat terjaga hingga mencapai tujuan yang diharapkan.

1. Pra-Survey dan analisis lingkungan melalui silaturahmi kepada stakeholders setempat Kegiatan ini bertujuan untuk identifikasi awal mengenai isu yang diangkat dalam PPM, yaitu pencegahan perdagangan manusia di Kecamatan Tempuran. Kegiatan ini bersifat formal karena tim PPM meminta izin kepada para stakeholders di Kecamatan Tempuran untuk menyelenggarakan kegiatan di wilayah tersebut. Kegiatan ini diselenggarakan pada Rabu, 8 Agustus 2018, yang berlokasi di kantor Kecamatan Tempuran dan di rumah salah satu tokoh masyarakat. Sasaran kegiatan ini yaitu stakeholders, diantaranya yaitu tokoh masyarakat, tokoh agama, tokoh pendidikan, aparat desa dan pemerintah kecamatan, tokoh pemuda (Karang Taruna) dan aparat keamanan. Pada kegiatan ini Kami melakukan survey pendahuluan dan silaturahmi kepada jajaran stakeholders di Kecamatan Tempuran, baik kepada tokoh masyarakat, tokoh agama, tokoh pendidikan, aparat desa dan pemerintah kecamatan, dan aparat keamanan. Kegiatan ini dijadikan sarana untuk mengumpulkan data primer dan sekunder dari berbagai lapisan masyarakat terkait dengan permasalahan perdagangan manusia. Pada kegiatan ini pula kami ingin mengetahui bagaimana pemahaman dan respon dari berbagai pihak terkait permasalahan perdagangan manusia. Kegiatan ini diawali dengan kunjungan kami terhadap perangkat kecamatan dengan maksud untuk memperkenalkan diri dan mengetahui potensi dan permasalahan di Kecamatan Tempuran. Juga ingin mengetahui upaya-upaya apa saja yang telah dilakukan oleh aparat pemerintah daerah setempat di dalam menanggulangi permasalahan perdagangan manusia. 


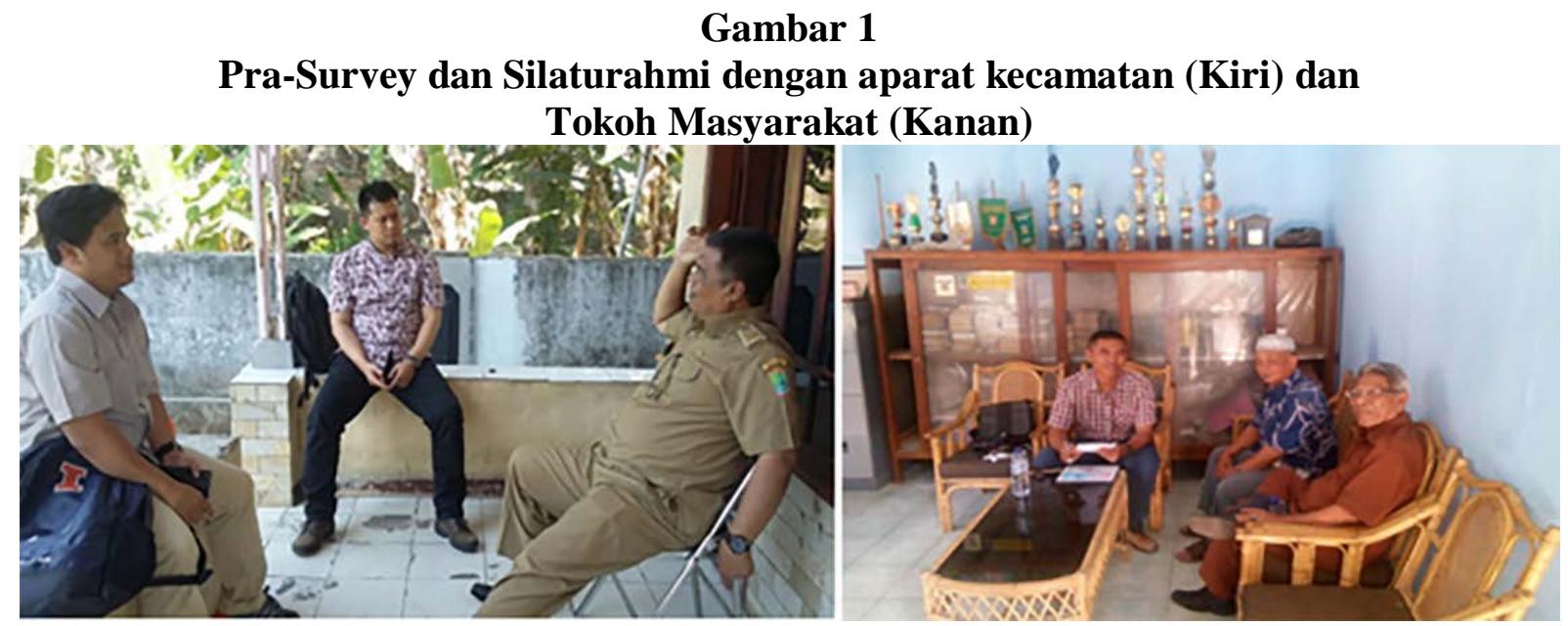

2. Wawancara dengan pihak Korban Perdagangan Manusia di Kecamatan Cilamaya Wetan

Kegiatan ini bertujuan untuk menggali lebih mendalam mengenai masalah perdagangan manusia yang terjadi di Kecamatan Tempuran khususnya, dan Kabupaten Karawang pada umumnya. Penggalian informasi ini bersifat semi formal, yaitu dipandu oleh pedoman wawancara yang telah dipersiapkan sebelumnya namun pedoman tersebut berkembang di lapangan dengan melihat respon dari informan. Kegiatan ini dilaksanakan pada Rabu, 29 Agustus 2018 yang berlokasi di tempat tinggal informan. Pihak yang diwawancarai yaitu dua korban dari perdagangan manusia dari kalangan perempuan dewasa maupun remaja. Pada tahapan kegiatan ini, kami ingin menggali pemahaman mengenai perdagangan manusia di Kecamatan Tempuran melalui korban dari perdagangan manusia tersebut. Tidak hanya para korban, tetapi juga para pelaku yang dengan kerelaan untuk melakukan tindakan prostitusi yang menjadi bagian dari perdagangan manusia di Kabupaten Karawang. Kegiatan ini sifatnya proaktif, yaitu mendatangi korban yang bersedia untuk memberikan informasinya terkait dengan perdagangan manusia di Kabupaten Karawang. Tidak banyak para korban yang bersedia berbagi informasi karena rasa kekhawatiran, ketakutan dan trauma yang mereka rasakan. Namun, kegiatan ini dilakukan dalam situasi yang nonformal dan berupa obrolan santai.

Berdasarkan hasil olah data, ditemukan bahwa iming-iming uang kerap menjadi pemikat yang belakangan justru menjerumuskan mereka ke lembah kelam. Anak-anak yang dieksploitasi sebagai pekerja seks umumnya ditawarkan upah 5 juta rupiah sebulan. Bahkan banyak teman-teman sebaya korban sudah yang 'sukses' menjadi Pekerja Seks Komersial (PSK) di Jakarta. Cerita-cerita tentang kehidupan mewah dan menjanjikan, kerap dikatakan 
teman-temannya yang pulang dari Jakarta. Banyak anak-anak di desanya yang berasal dari keluarga tidak mampu karena umumnya orangtua mereka hanya bekerja sebagai buruh tani ataupun TKW. Oleh sebab itu, mereka sering tergiur bila diiming-imingi pekerjaan dan penghasilan yang besar. Terdapat juga korban yang ditawari pekerjaan sebagai entertainer, dan mereka langsung tertarik. mereka membantu orangtuanya yang hanya bekerja sebagai buruh tani dan ibunya yang bekerja sebagai TKW. Jadi, mereka tidak menampik tawaran tersebut.

'Proyek' perdagangan anak yang terorganisir sudah banyak diketahui betul kalau di sejumlah desa di Kabupaten Karawang marak menjadi sasaran trafficking. Namun, untuk memberantasnya ternyata tidak semudah membalikkan telapak tangan. Ironisnya lagi, tak jarang orangtua dari anak-anak yang diperdagangkan tersebut, malah mendorong buah hatinya melakukan pekerjaan seks komersil. Uang selalu dijadikan faktor utama.

Melalui kegiatan wawancara dengan para pihak korban perdagangan manusia ini, kami memberikan masukan dan saran terkait penanggulangannya kepada para korban tersebut, meskipun hal tersebut sulit untuk dilakukan namun tampak dari para korban adanya peluang bagi perubahan kondisi sosial mereka ke arah yang lebih baik dengan jalan lain tanpa harus menjadi pelaku perdagangan manusia. Mereka juga akhirnya memahami modus-modus dari para pihak yang menjadi pelaku kejahatan ini dengan iming-iming kekayaan dan gaji yang besar tanpa mengetahui jenis dan tempat mereka bekerja. Sehingga, mereka mengetahui bagaimana cara bekerja di luar negeri jika ingin legal atau resmi dan menghindari bujukan atau iming-iming dari para calo pencari TKI Ilegal.

\section{Focus Group Discussion dengan stakeholders di Kecamatan Tempuran}

Kegiatan ini bertujuan untuk menggali permasalahan utama dari perdagangan manusia di Kabupaten Karawang, khususnya di Kecamatan Tempuran. Selain itu pula, wawancara ini juga untuk melakukan proses verifikasi data dan triangulasi data dari data yang sebelumnya telah dikumpulkan. Kegiatan ini diselenggarakan pada Kamis, 13 September 2018 dengan bertempat di salah satu rumah warga. Sasaran dari kegiatan ini adalah tokoh masyarakat dan perangkat kecamatan Tempuran yang terdiri dari Sekretaris Kecamatan dan Kabid Sosial. Informan dipilih didasarkan pada orang-orang yang menguasai informasi mengenai fenomena perdagangan manusia di Kecamatan Tempuran. Kegiatan ini bermaksud untuk menggali informasi mengenai permasalahan perdagangan manusia di Kecamatan Tempuran. Sekaligus ingin mengetahui respon dan upaya-upaya yang telah dilakukan oleh aparat pemerintahan (desa dan kecamatan) mengenai perdagangan manusia. 
Dari hasil analisis diskusi yang dilakukan, diketahui bahwa aparat pemerintah kecamatan dan warga masyarakat belum optimal melaksanakan Peraturan Daerah Kabupaten karawang Nomor 7 Tahun 2012 mengenai Pencegahan dan Penanganan Perdagangan Manusia . Hal ini didasarkan pada temuan peneliti bahwa mereka menganggap praktek migrasi ilegal biasa saja dan sudah lama terjadi dan bahkan calo atau germonya adalah warga masyarakat Karawang sendiri. Para guru di sekolah menjadi alat yang efektif di dalam melakukan pengawasan praktek perdagangan manusia di masyarakat.

Hasil dari FGD ini dapat menambah wawasan dan pengetahuan para aparat daerah dan tokoh masyarakat terkait dengan bahaya perdagangan manusia di Kecamatan Tempuran. Seluruh peserta memberikan respon yang positif untuk kegiatan penanggulangan perdagangan manusia di wilayahnya, terutama kalangan tokoh masyarakat dan tokoh agama. Mereka akan berupaya untuk menanggulangi perdagangan manusia sesuai dengan kapasitas dan kapabilitas yang dimilikinya. Terdapat komitmen dari peserta yang kami kunjungi untuk bersama-sama dan bekerjasama di dalam penanggulangan perdagangan manusia di Kecamatan Tempuran.

\section{Gambar 2}

\section{Focus Group Discussion dengan tokoh masyarakat (Kiri) dan} aparat keamanan (Kanan)
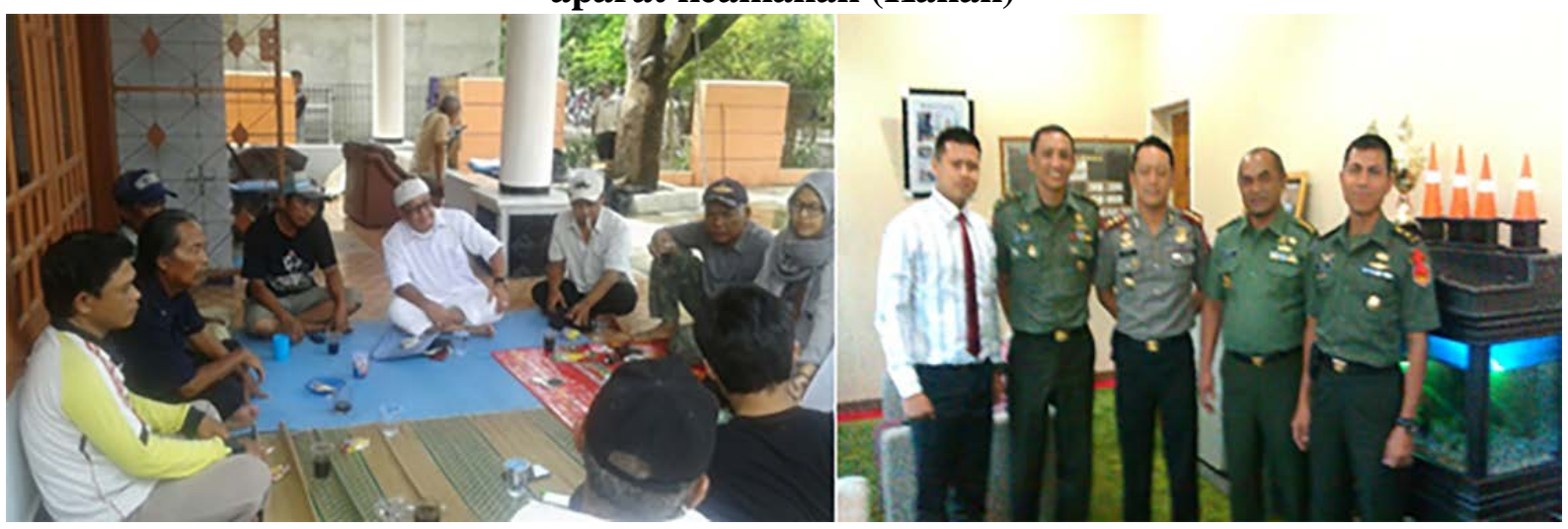

4. Diskusi dan nonton bareng Film "Whistleblower" dengan Siswa SMAN 1 Tempuran

Film "Whistleblower” bergenre drama dengan diwarnai aksi dan kriminal yang dirilis tahun 2011. Film ini menceritakan tentang perjuangan seorang perempuan yang menjadi aparat keamanan dalam mengatasi perdagangan manusia dimana ternyata pihak yang terlibat dalam praktek perdagangan manusia tersebut adalah oknum aparat keamanan yang memiliki back up kuat dari jabatan yang dimilikinya. Bentuk trafficking dalam film ini adalah perdagangan seks dan wanita sebagai pelacur. Cerita film yang diangkat dari kisah 
nyata ini sangat menarik ditonton dan dipelajari oleh mereka yang menaruh perhatian pada isu kemanusiaan. Kegiatan ini dilaksanakan di SMAN 1 Tempuran dengan sasaran kegiatan yaitu siswa kelas 13. Kegiatan ini bertujuan untuk memperkaya pengetahuan para siswa dimana ke depannya mereka kelak akan mencari kerja ataupun melanjutkan ke jenjang pendidikan lebih tinggi. Kegiatan ini memberikan pemahaman mengenai permasalahan perdagangan manusia melalui media visual dan memetik pelajaran dari film tersebut.

Kegiatan ini pula ingin mengajak dialog dengan para siswa dan membangkitkan kesadaran bersama terhadap bahaya dari perdagangan manusia bagi kelangsungan hidup para pelaku dan korbannya. Kegiatan ini diselenggarakan pada Kamis, 11 Oktober 2018. Pada kegiatan ini dilakukan diskusi santai dengan para siswa untuk menggali pemahaman mereka mengenai permasalahan perdagangan manusia di Kabupaten Karawang. Setelah diskusi dan menyaksikan film ini, peserta diskusi mendapatkan pemahaman baru mengenai bahaya perdagangan manusia terhadap kelangsungan hidup mereka, terutama terhadap kesehatan reproduksi, nilai agama dan sosial. Namun, sebagian masyarakat kesulitan untuk keluar dari jeratan perdagangan manusia dikarenakan kondisi ekonomi dan sosial yang menjerat kehidupan mereka.

Gambar 3

Diskusi dan nonton bareng film "Whistleblower" (Kiri) dan dokumentasi dengan para peserta (Kanan)

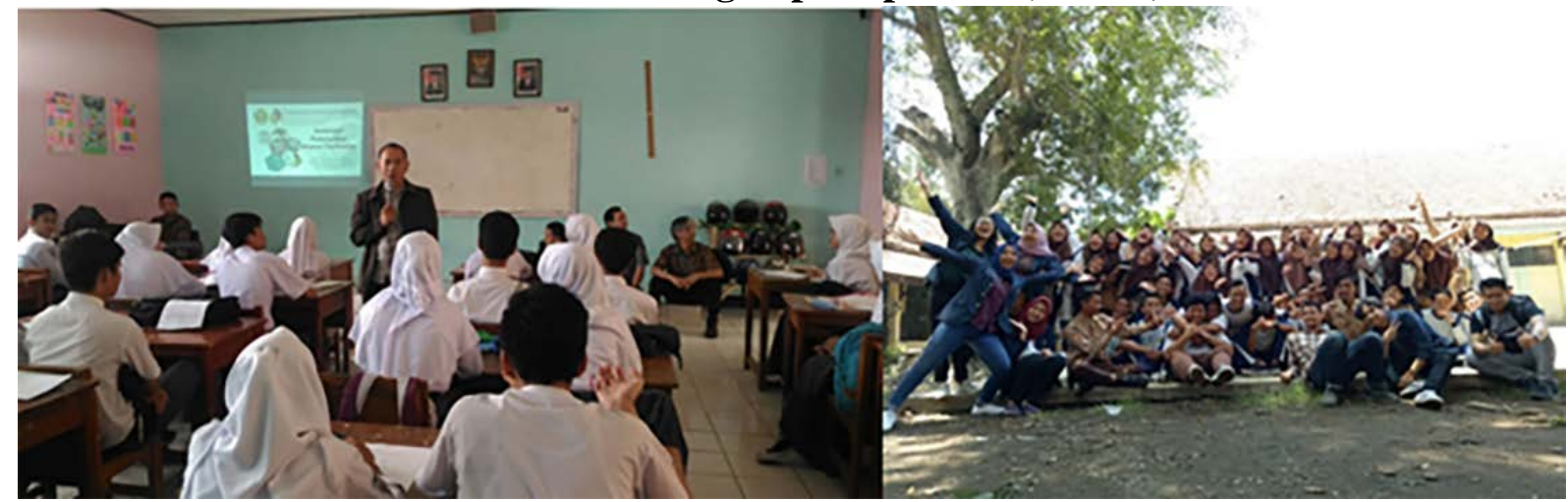

5. Sosialisasi pencegahan Perdagangan Manusia terhadap siswa di SMAN 1 Tempuran

Kegiatan sosialisasi ini bertujuan untuk memberikan penyadaran dan pengetahuan kepada para siswa mengenai masalah perdagangan manusia di Kecamatan Tempuran. Sosialisasi ditujukan pula untuk membangkitkan sikap penolakan para siswa terhadap kegiatan pihak-pihak yang berupaya untuk melakukan aktivitas perdagangan manusia dengan kedok bekerja di luar kota atau luar negeri. Kegiatan ini dilakukan pada Kamis, 8 November 2018 bertempat di ruang kelas siswa SMAN 1 Tempuran. Kegiatan ini merupakan kegiatan umum setelah dilakukannnya diskusi dengan aparat kecamatan, tokoh 
masyarakat, tokoh pemuda, dan pihak korban perdagangan manusia. Sosialisasi ini diharapkan memberikan pemahaman baru mengenai bahaya perdagangan manusia yang sasarannya yaitu para wanita dan remaja usia sekolah.

Peserta yang ikut menunjukkan antusias mereka dan memberikan respon di sela-sela kegiatan sosialisasi dengan berpartisipasi aktif di dalam proses tanya jawab. Hasil dari diskusi ini yaitu pernyataan sikap bersama dan komitmen bersama untuk menanggulangi perdagangan manusia di Kecamatan Tempuran, sembari membenahi kehidupan ekonomi mereka. Para siswa juga memberikan respon positif terhadap kegiatan ini dan memberikan komitmennya untuk belajar dan berprestasi agar kehidupan ekonomi mereka ke depannya menjadi lebih baik sehingga tidak terjerumus ke lubang perdagangan manusia. Di dalam kegiatan sosialisasi ini, dihasilkan suatu pernyataan dan sikap bersama terhadap perdagangan manusia di Kecamatan Tempuran. Poin-poin penting yang disepakati yaitu :

a. Penyadaran masyarakat untuk mencegah perdagangan manusia melalui sosialisasi kepada berbagai kalangan (aparat pemerintah daerah, tokoh masyarakat, tokoh agama dan pemuda, serta para korban perdagangan manusia).

b. Memperluas peluang kerja melalui pelatihan keterampilan kewirausahaan, pemberdayaan ekonomi dan lain-lain.

c. Peningkatan partisipasi pendidikan anak-anak baik formal maupun informal.

d. Kerjasama lintas kabupaten/provinsi dalam rangka pencegahan dan penanganan perdagangan manusia di Kecamatan Tempuran, karena perdagangan manusia merupakan isu lintas batas regional dan nasional sehingga perlu koordinasi dan kerjasama yang sinergis dengan berbagai pemangku kepentingan.

\section{Gambar 4}

Foto bersama Tim Pelaksana PPM dengan Wakil Kepala Sekolah SMAN 1 Tempuran setelah pelaksanan sosialisasi kegiatan
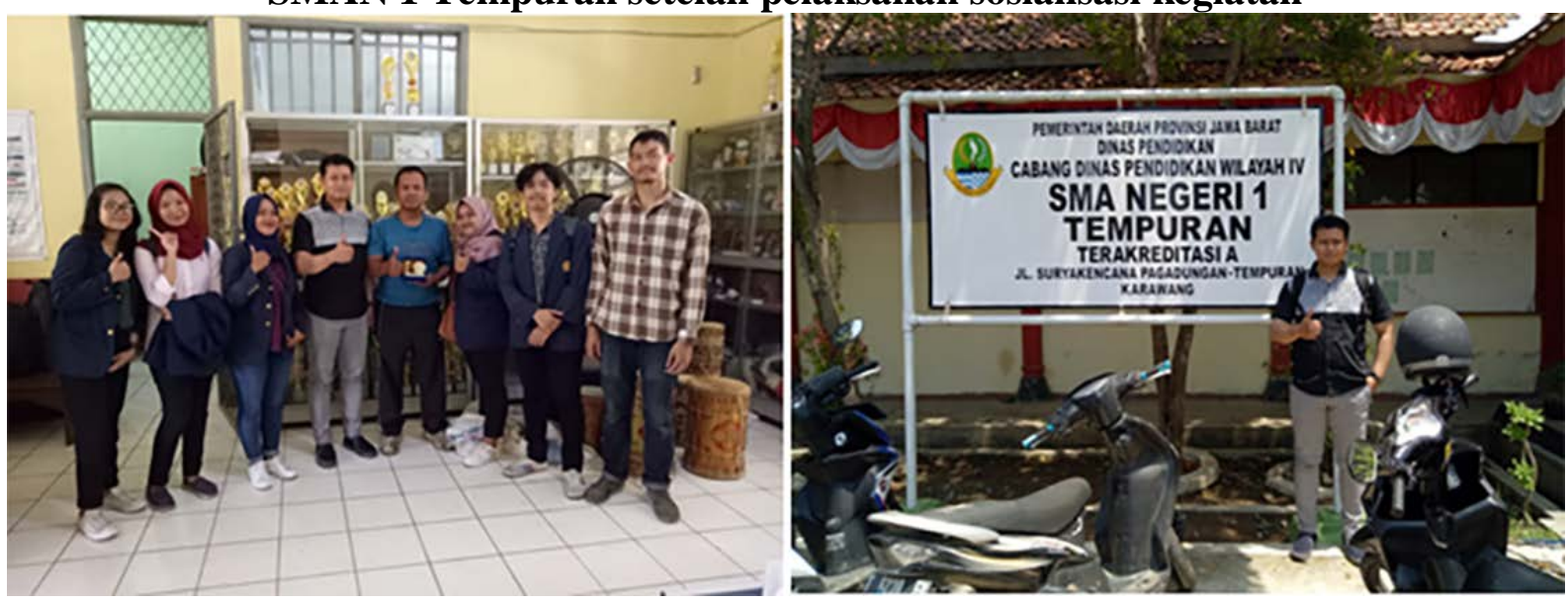


\section{SIMPULAN}

Berdasarkan hasil kegiatan yang dicapai, pelaksanaan pemberdayaan masyarakat melalui rangkaian kegiatan pengabdian pada masyarakat telah dilaksanakan dengan baik dan mendapatkan respon positif dari masyarakat sehingga diharapkan memberikan implikasi positif bagi pengamalan nilai-nilai insani dan sosial yang mampu membawa keharmonisan dalam bermasyarakat. Atas dasar kegiatan di atas, kami menyimpulkan bahwa kasus perdagangan manusia di Indonesia, khususnya di Kecamatan Tempuran Kabupaten Karawang tidak akan dapat sepenuhnya diatasi selama inti pemasalahannya belum terselesaikan. Faktor kemiskinan, gaya hidup masyarakat dan terbatasnya lapangan pekerjaan menjadi penyebab tingginya perdagangan manusia. Oleh karena itu, kegiatan penyadaran terhadap ancaman perdagangan manusia perlu dilakukan secara berkesinambungan mengingat penyebaran paham radikalisasi secara massif dapat tumbuh dan berkembang di era digitalisasi saat ini.

\section{DAFTAR PUSTAKA}

Andrijasevic, R. (2014). The Figure of Trafficked Victims: Gender, Right and Representation. United Kingdom: SAGE Publications Ltd.

Banks, S., \& Manners, P. (2012). Community-based participatory research A guide to ethical principles and practice, (November), 1-16.

Gasper, D. (2005). Securing Humanity: Situating ‘Human Security’ as Concept and Discourse. Journal of Human Development, 6(2), 221-245. https://doi.org/10.1080/14649880500120558

Ginkel, H. Van, \& Newman, E. (2000). In Quest of "Human Security". Japan Review of International Affairs, 14(1), 79.

O’Brien, E. (2018). Human Trafficking and Heroic Consumerism. International Journal for Crime, Justice and Social Democracy, 7(4), 51-66. https://doi.org/10.5204/ijcjsd.v7i4.430

Oberleitner, G. (2007). Global Human Rights Institutions: Between Remedy and Ritual. Cambridge: Polity Press.

Paris, R. (2001). Human Security: Paradigm Shift or Hot Air? 2International Security, 26(2), 87-102. https://doi.org/10.1162/016228801753191141

Permadi, A. (2017). Selama 2017, Kasus Trafficking di Jabar Tinggi. Retrieved from https://regional.kompas.com/read/2017/12/30/07571381/selama-2017-kasus-traffickingdi-jabar-tinggi 
Pudjiastuti, T. N., Wuryandari, G., \& Nur Alami, A. (2016). Perempuan dan Globalisasi: Studi Kasus Trafficking di Kabupaten Karawang. Jakarta: Pusat Penelitian Politik, Lembaga Ilmu Pengetahuan Indonesia.

Sallie, Y. (2010). Human Trafficking - A Geographical Perspective. Geodate, 23(3), 2.

Sapardjaja, K. E. (2003). Trafficking Perempuan dan Anak di Jawa Barat (Studi Kasus di Kabupaten Bandung, Indramayu dan Karawang). Sosiohumaniora, 5(2), 131-147. https://doi.org/https://doi.org/10.24198/sosiohumaniora.v5i2.5297

Sidebang, E. M. (2018). Awasi, Atasi, Antisipasi Permasalahan Human Trafficking di Kabupaten Karawang. Retrieved from https://www.faktajabar.co.id/2018/07/11/awasiatasi-antisipasi-permasalahan-human-trafficking-di-kabupaten-karawang/

Thomas, C., \& Wilkin, P. (1999). Globalization, Human Security and the African Experience. Boulder, Colo: Lynne Rienner.

UNODC. (2017). UNODC report on human trafficking exposes modern form of slavery. Retrieved from http://www.unodc.org/unodc/en/human-trafficking/global-report-ontrafficking-in-persons.html

Winarsih, I. N. (2017). 12 Kecamatan di Karawang Jadi Kantong Perdagangan Manusia. Retrieved from https://www.republika.co.id/berita/nasional/daerah/17/11/15/ozgdxv38412-kecamatan-di-karawang-jadi-kantong-perdagangan-manusia 